\title{
Assault and Battery, or Legitimate Treatment?
}

German Legal Debates on the Status of Medical Interventions without

Consent, c. 1890-1914

Andreas-Holger Maehle

\section{Summary}

In response to cases of high-handed medical interventions and treatments, a debate on the legal justification of operations and the relevance of patients' consent developed among German-speaking jurists in the 1890s. The view that surgery was objectively physical injury or battery, which went merely unpunished through the patient's consent, was highly contested among legal experts and firmly rejected by doctors. Various proposals to justify indicated medical treatment without consent were discussed. German jurisdiction, however, endorsed the battery theory of medical interventions and thus prepared the way for the concept of informed consent in medicine.

\section{Introduction}

In German jurisdiction, medical interventions constitute factually assault and battery (Körperverletzungen) in the sense of criminal and civil law ${ }^{1}$. In order to go unpunished they require a special justification, which is recognized in the consent of the patient or his legal representative. This conception of legality was established about a century ago, but was at the time highly contested among leading jurists. Moreover, it earned forceful protests from the medical profession. In 1899, for example, the Munich professor of surgery Ottmar von Angerer (1850-1918) wrote:

1 Otto Tempel, «Inhalt, Grenzen und Durchführung der ärztlichen Aufklärungspflicht unter Zugrundelegung der höchstrichterlichen Rechtsprechung», Neue Juristische Wochenschrift 33 (1980) 609-617, with reference to § $223 \mathrm{StGB}$ and $\$ 832$ I BGB.

Prof. A.-H. Maehle, Dept. of Philosophy, University of Durham, 50 Old Elvet, Durham DH1 $3 \mathrm{HN}$, Great Britain. 
Why should a doctor who skilfully removes with one cut a malignant tumour, thereby freeing a human being from pain and suffering or even saving the patient's life through his operation, be treated on the same level as a rowdy: here is the hostile intention to harm, there the will to be useful, to help. [...] we have to emphasize firmly the point that we can never take our medical and surgical interventions as physical assault and bodily maltreatment in the sense of the Criminal Code ${ }^{2}$.

However, the debate on the legal status of medical interventions (ärztliche Eingriffe) had its reasons. It had been initiated, and was sustained, by cases in which doctors had operated without or with dubious consent and were subsequently taken to court. The meaning and limits of patients' consent played therefore a major role in the legal considerations of this issue. The analysis of these, hitherto underresearched legal discussions can thus bring a new aspect to the history of informed consent in medicine - a history, which has to date been explored predominantly from the doctors' perspective ${ }^{3}$ and with regard to human experimentation ${ }^{4}$. The rise of science-based hospital medicine in late nineteenth-century Germany, which was linked with a weakening of the patient's position towards the doctor, has been identified by historians as the background to contemporary abuses in clinical research ${ }^{5}$. In this connection, the directive of the Prussian Minister of Religious, Educational and Medical Affairs to the heads of clinics and hospitals on "medical interventions other than those for diagnostic, therapeutic, and

2 Cf. Ottmar von Angerer, «Die strafrechtliche Verantwortlichkeit des Arztes», Münchener Medicinische Wochenschrift 46 (1899) 351-356, on 351 and 356. Similarly the Leipzig doctor J. Thiersch, «Sind chirurgische Operationen und operative Eingriffe körperliche Misshandlungen im strafrechtlichen Sinne?», Aerztliches Vereinsblatt für Deutschland 23 (1894) 473-479; and the Berlin gynaecologist Alfred Dührssen, «Strafgesetzbuch und ärztliche Operationen», Berliner Aerzte-Correspondenz 8 (1903) 13-14.

3 Barbara Elkeles, «Die schweigsame Welt von Arzt und Patient: Einwilligung und Aufklärung in der Arzt-Patienten-Beziehung des 19. und frühen 20. Jahrhunderts», Medizin, Gesellschaft und Geschichte 8 (1989) 63-91. Elkeles mentions the most relevant legal cases, but does not discuss details of the debates on the legal status of operations.

4 B. Elkeles, Der moralische Diskurs über das medizinische Menschenexperiment im 19. Jahrhundert (Stuttgart 1996); Susan E. Lederer, Subjected to Science: Human Experimentation in America before the Second World War (Baltimore 1995); Giovanni Maio, «Das Humanexperiment vor und nach Nürnberg: Überlegungen zum Menschenversuch und zum Einwilligungsbegriff in der französischen Diskussion des 19. und 20. Jahrhunderts», in: Claudia Wiesemann/Andreas Frewer (eds), Medizin und Ethik im Zeichen von Auschwitz: 50 Jahre Nürnberger Ärzteprozess (Erlangen 1996) 45-78; Ulrich Tröhler/Stella Reiter-Theil (eds), Ethics Codes in Medicine: Foundations and Achievements of Codification since 1947 (Aldershot 1998).

5 Elkeles, op. cit. (note 4), and B. Elkeles, «Der Patient und das Krankenhaus», in: Alfons Labisch/Reinhard Spree (eds), ‘Einem jeden Kranken in einem Hospitale sein eigenes Bett. Zur Sozialgeschichte des Allgemeinen Krankenhauses in Deutschland im 19. Jahrhundert (Frankfurt/Main 1996) 357-373; Rolf Winau, «Medizin und Menschenversuch. Zur Geschichte des «informed consent»», in: Wiesemann/Frewer, op. cit. (note 4) 13-29; C. Wiesemann, «Das Recht auf Selbstbestimmung und das Arzt-Patient-Verhältnis aus sozialgeschichtlicher Perspektive», in: Richard Toellner/Urban Wiesing (eds), Geschichte und Ethik in der Medizin. Von den Schwierigkeiten einer Kooperation (Stuttgart 1997) 67-90. 
immunisation purposes" has often been highlighted. Issued at the end of the year 1900 in response to the notorious "Neisser case" ${ }^{\text {, }}$ it introduced the requirements of information and consent of subjects in clinical trials and prohibited experiments on minors and other legally incompetent persons ${ }^{7}$. This paper will show how another strand in the history of patients' consent originated from cases of high-handed medical interventions within therapeutic settings, that clashed with contemporary legal notions of self-determination and bodily integrity. It will also demonstrate how some jurists, who were sympathetic towards doctors' resentment of equating surgery with physical injury, tried to find ways around this problem, but eventually failed.

As Martin Pernick has argued, nineteenth-century American courts tended to judge operations without consent as malpractice, provided there had been no reasons to refrain from informing and asking the patient in the interest of his health. Yet from the 1890s onwards they began to treat cases of involuntary surgery under battery law $^{8}$. Of particular importance for this new approach became the opinion of Justice Benjamin Cardozo in the case of "Schloendorff v. The Society of New York Hospitals (1914)"':

Every human being of adult years and sound mind has a right to determine what shall be done with his own body; and a surgeon who performs an operation without his patient's consent commits an assault, for which he is liable in damages ${ }^{10}$.

This paper will analyse how some German jurists around the turn of the century had arrived at the same conclusion.

6 Injection experiments with cell-free syphilitic serum (to test its preventive power), carried out on hospital patients by the Breslau professor of dermatology and venereology Albert Neisser without information or consent; for details see B. Elkeles, «Medizinische Menschenversuche gegen Ende des 19. Jahrhunderts und der Fall Neisser», Medizinhistorisches Journal 20 (1985) 135-148; Elke Tashiro, Die Waage der Venus: Venerologische Versuche am Menschen zwischen Fortschritt und Moral (Husum 1991) 84-104; Elkeles, op. cit. (note 4) 180-217.

7 Ibid., 209; Jochen Vollmann/R. Winau, "Informed Consent in Human Experimentation before the Nuremberg Code", British Medical Journal 313 (1996) 1445-1447; idem, "History of Informed Medical Consent", The Lancet 347 (1996) 410; J. Vollmann, «Das Informed Consent-Konzept als Politikum in der Medizin. Patientenaufklärung und Einwilligung aus historischer und medizinethischer Perspektive», in: Matthias Kettner (ed.), Angewandte Ethik als Politikum (Frankfurt/Main 2000) 253-279.

8 Martin S. Pernick, "The Patient's Role in Medical Decisionmaking: A Social History of Informed Consent in Medical Therapy", in: President's Commission for the Study of Ethical Problems in Medicine and Biomedical and Behavioral Research, Making Health Care Decisions 3 (Washington 1982) 1-35.

9 Operative removal of a fibroid tumour, against the patient's wishes, under ether narcosis; see Jay Katz, The Silent World of Doctor and Patient (New York 1986) 51. See also Ruth R. Faden/Tom L. Beauchamp/Nancy M. P. King, A History and Theory of Informed Consent (New York 1986) 123.

10 Ibid. 


\section{The controversy between Oppenheim and Stooss}

The starting point of the debate on the legal status of medical interventions was a controversy between the penologist Lassa Oppenheim (1858-1919), who in 1892 had moved from an associate professorship at the University of Freiburg (Breisgau) to a professorship and subsequently chair at Basle ${ }^{11}$, and Carl Stooss (1849-1934), who held the chair of criminal law in Berne and, in 1896, became professor of law in Vienna ${ }^{12}$. Stimulated among others by a Basle legal case of the year 1882, Oppenheim gave his inaugural lecture on the topic "The Medical Right to Bodily Interventions on Sick and Healthy Persons" ${ }^{13}$. In this case a Basle doctor had cut twenty-four small pieces of skin from the upper arms and thighs of a 15 -year-old servant girl - with her consent - in order to transplant them on a badly healing wound of her female employer. As the pieces of skin were taken off, the girl had started to cry; but this did not stop the doctor in completing the procedure. The father of this minor servant girl reported the doctor to the police, because the operation had been carried out without his approval. The public prosecutor subsequently charged the doctor with assault and battery according to $\$ 108$ of the Basle Criminal Code. The Criminal Court of Basle City, however, acquitted the doctor. It had come to the conclusion that minor assaults with consent were not to be punished, and that the girl was able to foresee the consequences of her consent ${ }^{14}$. For Oppenheim, this acquittal was a miscarriage of justice, because the consent of the father had not been obtained, although this would have been possible ${ }^{15}$. In another, more recent case (dating from 1892) the Kassel District Court had convicted a psychiatrist of assault and battery according to $\S 223$ of the German Criminal Code ${ }^{16}$. In order to quieten a hysterically screaming patient in his private clinic, he had repeatedly beaten her: with his hand, with a stick, and finally with a riding whip. The defendant's claims that this was legitimate therapeutic treatment were dismissed by the $\operatorname{court}^{17}$. Here Oppenheim agreed with the judgement, pointing

11 Rudolf Thommen, Die Universität Basel in den Jahren 1884-1913 (Basle 1914) 44. Thanks to Monika Butz, Universitätsbibliothek Basel, for this reference.

12 Stooss is best known for his contributions to the drafting of the Swiss Criminal Code during the years 1892-96; see Michael Stolleis (ed.), Juristen: Ein biographisches Lexikon. Von der Antike bis zum 20. Jahrhundert (Munich 1995) 589.

13 Lassa Oppenheim, Das ärztliche Recht zu körperlichen Eingriffen an Kranken und Gesunden (Basle 1892).

14 Cf. ibid., appendix, 43-48. Oppenheim published here extracts from the official files.

15 Ibid., 27-28.

16 "Someone who intentionally mistreats somebody else's body or harms that person's health, will be punished for assault and battery with imprisonment up to three years or a fine up to one thousand mark." (Cf. $\$ 223$ StGB).

17 Cf. Oppenheim, op. cit. (note 13), appendix, 48-63 (transcript of the opinion). 
out that immoral means of treatment could not be justified and that corporeal punishment was not covered by entering deliberately an authoritarian doctor-patient relationship ${ }^{18}$.

In Oppenheim's view, these two cases illustrated how necessary it was "to explore the legal basis and limits of doctors' right to bodily interventions"19. Accordingly he raised two general questions: firstly, that of the legal justification (Rechtsgrund) of medical interventions, and secondly that of the legal relevance of patients' consent.

Some leading experts in criminal law had already briefly addressed these problems. The Bonn professor Hugo Hälschner (1817-1889) derived the legitimacy of medical therapeutic interventions from the consent of the patient. Generally, battery with consent could not go unpunished. The proposition of Roman Law, Volenti non fit iniuria (i.e. "A consenting person cannot be wronged"), was not applicable to bodily integrity, because health constituted a legally inalienable good ${ }^{20}$. However, Hälschner saw an exception in the case of therapeutic interventions. The moral duty of the patient to preserve his life, he argued, entitled the patient to give consent to the doctor's operation ${ }^{21}$.

Law professors Franz von Liszt (1851-1919) in Marburg and Karl Binding (1841-1920) in Leipzig regarded the right to operate as a specific professional right of doctors. In von Liszt's opinion this included surgical procedures as well as the perforation of the fetus ${ }^{22}$, but he raised the question whether, and on which conditions, a doctor could proceed without the consent of the patient or the patient's relatives ${ }^{23}$. Binding emphasized that operations must not be performed against the will of a patient of sound mind, or a patient's

18 Ibid., 26-27.

19 Cf. ibid., 4. Oppenheim was also alarmed by contemporary reports on human experimentation, such as those on autotransplantation of breast cancer tissue in patients of a Paris hospital (ibid., 35-36; cf. Elkeles, op. cit. [note 4] 180). While insisting that no person should ever be subjected to experimentation without her consent, he acknowledged that abuses in this area resulted from "a burning desire for research and the hope to help other sufferers", and he believed - rather naively - that these abuses would stop once doctors had been "educated about the limits of their right to physical interventions in ill and healthy people". Cf. ibid., 4, 35.

20 Cf. Entscheidungen des Reichsgerichts in Strafsachen 2 (1880), 442-443 (decision of 15 November 1880); Hugo Hälschner, Das gemeine deutsche Strafrecht systematisch dargestellt 1 (Bonn 1881) 469-471. For a discussion of this problem see R. Kessler, Die Einwilligung des Verletzten in ihrer strafrechtlichen Bedeutung (Berlin 1884) esp. 76-79.

21 Hälschner, op. cit. (note 20) 471.

22 Perforation (craniotomy) of the fetus, which led to its death, was performed in order to save the mother's life if natural delivery was otherwise impossible, mostly because of a narrow, rachitic pelvis. The alternative, Caesarean section, had a very high risk of mortality for the mother. For contemporary debates on this difficult ethical issue see Elkeles, op. cit. (note 3) 76-83.

23 Franz von Liszt, Lehrbuch des Deutschen Strafrechts (Berlin 21884) 124-125. 
relatives in cases of unconsciousness or mental illness. However, he was prepared to accept medical interventions in the absence of consent in unconscious patients, children, and the mentally ill, even against possible patient resistance, or in the knowledge that the conscious person would have refused consent. His only condition was here that the doctor had been called for help ${ }^{24}$.

Oppenheim saw difficulties with these opinions. Some medical interventions, he said, were rightly carried out against the will of the patient, for example in treating someone who has made a suicide attempt ${ }^{25}$. Some operations had no moral purpose in the sense of Hälschner, for example those of purely cosmetic surgery ${ }^{26}$. Finally, there was no professional right that could support a layperson who carries out an appropriate surgical procedure in a medical emergency, and yet nobody would want to charge this person with assault and battery. Conversely, not every doctor was entitled to perform any operation, but only those for which he had the necessary skills ${ }^{27}$. Thus, according to Oppenheim, neither patients' consent, nor the moral purpose, nor a professional right could form the legal justification (rechtliches Fundament, Rechtsgrund) of medical interventions. In his view they had to be explained quite simply by common law (Gewohnheitsrecht).

Medical interventions, he maintained, had been carried out for "thousands of years" without interference by the law. This meant that the "medical purpose" (ärztlicher Zweck) was their common law basis. However, interventions with such a purpose had to fulfil certain "conditions" in order to satisfy the population's sense of justice ${ }^{28}$. At this point Oppenheim introduced the central requirement of consent. In agreement with his teacher Binding he stated the principle that no mentally healthy adult had to tolerate medical treatment against his will. Moreover, Oppenheim left no doubt that any operation, be it as large or as small as it may be, did require the specific consent of the patient (except in medical emergencies, including suicide attempts). Moreover, in critical operations "the full danger of the procedure" had to be brought to the patient's attention in advance, i.e. information about risks was deemed necessary in such $\operatorname{cases}^{29}$. As Oppenheim made entirely clear in a subsequent article, operations without consent constituted punishable assault and battery ${ }^{30}$.

24 Karl Binding, Handbuch des Strafrechts 1 (Leipzig 1885) 801-802.

25 Oppenheim, op. cit. (note 13) 10-11.

26 Ibid., 12-13; same objection in Kessler, op. cit. (note 20) 78.

27 Oppenheim, op. cit. (note 13) 14-16.

28 Ibid., 16-20.

29 Ibid., 22-23.

30 L. Oppenheim, «Die rechtliche Beurteilung der ärztlichen Eingriffe», Zeitschrift für Schweizer Strafrecht 6 (1893) 332-352, on 339, 347. 
Oppenheim's inaugural lecture provoked harsh criticism from Carl Stooss in Berne. His critique was chiefly directed against the legal justification of operations with their "medical purpose" in the context of common law. As the Berne professor pointed out, decisive for the legal evaluation of an operation was not its general medical purpose, but whether it was based on the right diagnosis, whether it was appropriate, and whether it had been performed lege artis. Since an inappropriate operation could be carried out by a doctor with best therapeutic intentions, its purpose could not serve as its legal basis ${ }^{31}$. Moreover, Stooss challenged Oppenheim's application of common law, since this required that a legal maxim had been accepted and followed by the population for a long time. Oppenheim's "conditions", he claimed, did not fulfil this requirement ${ }^{32}$.

More important than this critique, however, became Stooss's own conception of legality concerning medical interventions and his views on consent. Against Oppenheim, and against the various doctrines of a special legal justification, he tried to show that surgical operations did principally not constitute battery in the sense of criminal law. Legally relevant was the success of an operation. If an operation was successful, he argued, there could not be a case of battery, because the patient had not been harmed. If an operation failed, this result was objectively illegal. However, if the surgeon had been in error about the anticipated success, and this error was excusable, then this result was equivalent in criminal law to a real success, i.e. the surgeon had to be acquitted ${ }^{33}$. Thus, Stooss dismissed the battery theory of medical interventions in the field of criminal law. This, however, weakened the requirement of consent that had been so central in Oppenheim's analysis. For Stooss, a need for consent-seeking arose merely from the perspective of private (civil) law, and failure to obtain consent (where this had been possible) was an infringement, not a crime:

Since nobody is obliged to submit to any physical treatment, unless an exception has been defined in the law, the doctor needs the consent of the patient to the operation, perhaps the consent of the guardian, as far as circumstances permit to obtain the consent. Can a doctor who operates without the patient's consent, and damages him by this, be sentenced to pay compensation in the absence of any other fault? It would be recommendable in any case to fine a doctor if he operates without the patient's consent ${ }^{34}$.

A doctor was entitled to operate, concluded Stooss, if the operation seemed necessary in the interest of the patient's health, on the basis of medical experience and science ${ }^{35}$.

31 Carl Stooss, «Operativer Eingriff und Körperverletzung», ibid., 53-61, on 58-59.

32 Ibid., 60.

33 Ibid., 54-55, 60-61.

34 Cf. ibid., 57.

35 Ibid., 60 . 
Oppenheim emphatically defended his position, stating that his common law approach to the problem rested on his extensive study of medical literature and his personal conversations with doctors. Moreover, no reasonable person would deny that even a successful operation, such as a leg amputation, ovariotomy, or trepanation, constituted physical injury ${ }^{36}$. This became obvious if such operations were carried out without the patient's consent or even against his will:

I have no doubt that the courts, having heard medical experts, will punish a doctor who operates against the patient's will, for battery and coercion. [...] It has to be left to the patient whether he wants to be made a cripple and healed, or whether he wants to stay ill or even die. [...] The doctor does not yet rule the world, it is still a matter of personal trust whether I want to surrender to the doctor or not. And it is good that it is like that! ${ }^{37}$

\section{The Hamburg and Dresden cases, and the widening of the debate}

Only a year later, in 1894, these controversial opinions were tested in a Hamburg case, which went as far as to the Supreme Court of the German Reich (Reichsgericht). In a 7-year-old girl a surgeon had performed a medically indicated resection of tuberculous and purulent bones of her forefoot - against the explicit will of her father. On the day of the operation, the girl already being under an anaesthetic in the operating theatre, her father had even tried to take her out of the hospital. The surgeon was subsequently taken to court for assault and battery according to $\S 223$ of the German Criminal Code. Though the case ended with the acquittal of the surgeon on a technicality ${ }^{38}$, the Supreme Court endorsed the legal view that operative interventions constitute objectively assault and battery. They were punishable, stated the Court, if the doctor could not derive his right to operate "from an existing contractual relation or the presumptive consent, the assumed brief of duly legitimized persons" 39 . In other words, the Supreme

36 Oppenheim, op. cit. (note 30) 336, 339.

37 Cf. ibid., 348. Stooss replied by insisting that successful operations did not constitute physical injury in the sense of criminal law and by elaborating on his critique of Oppenheim's justification with common law. See C. Stooss, «Ist der ärztliche Zweck das gewohnheitsrechtliche Fundament zum ärztlichen Eingriff?», Zeitschrift für Schweizer Strafrecht 7 (1894) 192-198.

38 When the father wanted to intervene, the girl's leg had already been made bloodless (Esmarch's method), and the medical experts in the case agreed that restoring the bloodflow at this point without having performed the resection of the purulent bones would have carried the risk of septicaemia. The surgeon, being solely responsible in this situation, therefore had to operate in order to avert an imminent danger. Cf. Carl Stooss, Chirurgische Operation und ärztliche Behandlung. Eine Strafrechtliche Studie (Berlin 1898), appendix, 124-125 (second verdict of the Hamburg District Court, 13 December 1894).

39 Cf. Entscheidungen des Reichsgerichts in Strafsachen 25 (1894) 375-389 (decision of 31 May 1894), on 382. 
Court supported the position of Oppenheim and contradicted the view of Stooss $^{40}$.

Unflustered by this, however, Stooss went even a step further in his legal argumentation. In 1898 he published a monograph in which he distanced himself from his earlier argument of the success of surgical procedures. Instead he now tried to demonstrate that medical operations "by their very nature" could not be physical injuries. His central argument was that operations were health-improving treatments, not mistreatments in the sense of the Criminal Code ${ }^{41}$. With reference to the Hamburg case he admitted that an infringement of the "rights of paternal authority" had happened here; but this did not mean that the treatment had turned into assault and battery ${ }^{42}$.

This, as it were, "soft" concept had implications for the question of consent. For Stooss, the requirement of patients' consent followed in principle from the liberty of the person and her authority over her own body. Moreover, he demanded full information of the patient in order to obtain consent that was legally valid ${ }^{43}$. However, he made important concessions to the prevalent medical paternalism of his time:

If the doctor finds that the patient is unable to bear the truth, he should not bother the patient at all with consent-seeking for the treatment, and turn [instead] to the relatives, in an emergency, however, act according to his dutiful judgement ${ }^{44}$.

This was clearly in line with the sentiments of leading surgeons. Von Angerer, for example, asserted that "we see every high-handed treatment of a patient as an intrusion upon his personal freedom" 45 , and his Göttingen colleague, Franz König (1832-1910), assured that "we regard it [...] as illegal to perform any bloody, painful, or dangerous intervention without the specific consent of the patient" 46 . Yet these general statements were considerably qualified. As von Angerer observed, "frequently the most intelligent people behave in their illness like unreasonable children who want what is most wrong for them". In such cases it was better to obtain the relatives' consent ${ }^{47}$. In emergencies, an operation not only against the presumed wishes of the patient ${ }^{48}$,

40 By 1896, a first law thesis on the two conflicting positions had been completed under the supervision of Karl von Lilienthal at the University of Marburg: H. Dietrich, Die Straflosigkeit ärztlicher Eingriffe (Fulda 1896). Dietrich argued that medical interventions were justified through their necessity, yet followed Oppenheim in the requirement of consent.

41 Stooss, op. cit. (note 38) preface, and 6, 9-10, 18.

42 Ibid., 23.

43 Ibid., 27, 31.

44 Cf. ibid., 31.

45 Cf. von Angerer, op. cit. (note 2) 353.

46 Cf. Franz König, «Der Arzt und der Kranke. Mit besonderer Berücksichtigung des Krankenhausarztes», Zeitschrift für sociale Medicin 1 (1895) 1-11, on 6.

47 Cf. von Angerer, op. cit. (note 2) 355.

48 Ibid., 353. 
but also against the will of guardians ${ }^{49}$, was permissible from the medical point of view. In general, patients were quite simply expected to give their consent to the treatment that the doctor suggested. If they refused it, there was only one solution according to König: they had to leave the hospital ${ }^{50}$.

The reactions of legal experts to Stooss's views were divided. Joseph Heimberger (1865-1933), associate professor of law at Strassburg ${ }^{51}$, largely agreed with him, arguing that a medically indicated operation was an appropriate treatment, and therefore no battery ${ }^{52}$. An indicated and successful operation against the patient's will could thus not be punished according to $\S 223$ of the German Criminal Code, though possibly according to $§ 239$ (wrongful deprivation of personal liberty) or $\$ 240$ (coercion). However, as Heimberger pointed out, even then a conviction would only be possible if the doctor had been aware of the illegality of his action. A doctor, for example, who performed against the parents' wishes an indicated tracheotomy in a child suffering from diphtheria, would therefore be covered ${ }^{53}$. In general, Heimberger acknowledged the need for consent-seeking, but he was satisfied with tacit consent of the patient that was apparent from "conclusive actions" 54 .

By contrast, the dean of the Heidelberg faculty of law, Karl von Lilienthal (1853-1927), thought that the low esteem for consent in Stooss was "in practice an immensely worrying conclusion" 55 . Like Oppenheim, he saw consent as a "barrier" to medical actions; and he even suggested to insert a special regulation on operations without patients' consent into the Criminal Code. Against Stooss, von Lilienthal held on to the theory of operations as battery and recognized their medical purpose as the special legal reason for their impunity in principle ${ }^{56}$. The patient had to be informed about the risks and consequences of an operation. The patient's "fear of the operation" was no excuse, though the details of the procedure had not to be told:

49 König, op. cit. (note 46) 7-8.

50 Ibid., 8. The Berlin psychiatrist and writer on medical professional ethics Albert Moll suggested that the doctor denies further treatment in such cases. Any treatment against the patient's will would breach the (tacit) contract underlying the doctor-patient relationship. Cf. A. Moll, Ärztliche Ethik. Die Pflichten des Arztes in allen Beziehungen seiner Thätigkeit (Stuttgart 1902) 262-263.

51 Heimberger had made a name for himself with a monograph on the problem of perforation of the fetus (see note 22) in relation to $\$ 218$ StGB (abortion): Joseph Heimberger, Über die Straflosigkeit der Perforation (Berlin 1889).

52 J. Heimberger, Strafrecht und Medizin (Munich 1899) 43, 51-52.

53 Ibid., 55-57, 60-61.

54 Ibid., 58.

55 Karl von Lilienthal, «Die pflichtmässige ärztliche Handlung und das Strafrecht», in: Festgabe zur Feier des fünfzigsten Jahrestages der Doktor-Promotion des Geheimen Rates Professor Dr. Ernst Immanuel Bekker dargebracht von den Mitgliedern der Juristischen Fakultät der Universität Heidelberg (Berlin 1899) 1-57, on 20.

56 Ibid., 37-48, 56-57. 
Around this time a new case caused a sensation. Examining a woman who was already in narcosis for a curettage of the womb (because of endometritis), the Dresden gynaecologist Otto Ihle had found that she had cystic ovarian tumours on both sides. Because of this, he had immediately performed a laparatomy and removed both ovaries. When the patient was afterwards informed about the extent of the operation, and its reasons, she was initially grateful; but later she refused to pay the fee, and Ihle took her to court for this. The patient in turn now demanded compensation for pain and physical damage. The Dresden High Court concluded that Ihle had caused "intentional and illegal bodily harm" (absichtliche und widerrechtliche Körperverletzung), it rejected his claim for the fee as well as the patient's for compensation (because she had "forgiven" him in expressing her initial gratefulness), and it passed on the file to the public prosecutor. The prosecutor, however, abstained from starting criminal proceedings against the doctor $^{58}$.

Ihle vigorously defended himself in public, arguing that he had correctly "presumed" the patient's consent, in line with the Supreme Court decision in the Hamburg case. Moreover, it would have been "barbaric" to wake the patient up from her narcosis and "frighten and weaken her even more through detailed information about her disease, so that she finally won't survive the operation" ${ }^{9}$. He even submitted a petition on this matter to the Saxon Landtag, which however proceeded to the agenda without considering it ${ }^{60}$.

Parts of the medical and daily press were sympathetic towards Ihle's position. An article in the Berliner Börsenzeitung claimed that the Dresden verdict brought doctors in a no-win situation: they would be prosecuted for performing surgical procedures that turned out to be urgent during narcosis, and they could likewise be punished if they failed to act or endangered the patient's life through delay ${ }^{61}$. Some medical and legal commentators, however, argued that in this Dresden case the operation should have been postponed in order to obtain the patient's consent. There had been no emergency

57 Cf. ibid., 48.

58 Cf. Verdict of High Court (Oberlandesgericht) Dresden of 7 October 1897, reported in Deutsche Juristen-Zeitung 4 (1899) 199-200. See also Heimberger, op. cit. (note 52) 2-4; Karl Anton Ewald, «Ueber den Fall I. in Dresden», Berliner Klinische Wochenschrift 36 (1899) 139-14.0.

59 Cf. Dresdener Nachrichten, Nr. 50, 19 February 1899, in: Geheimes Staatsarchiv Preussischer Kulturbesitz (GStAPK) I. HA Rep. 76 VIII B, Nr. 785.

60 Ewald, op. cit. (note 58) 139.

61 Berliner Börsenzeitung, Nr.43,1899, in: GStAPK I. HA Rep.76 VIII B, Nr. 785. Also in defence of Ihle, «Der Fall Ihle», Aerztliche Rundschau, Nr. 8, 1899, ibid. 
situation, which in common legal opinion would have justified an operation without consent ${ }^{62}$.

Opinions were likewise divided with regard to the Dresden High Court's identification of the operation as a case of battery. Stooss published several articles, both in legal and medical journals, giving again his reasons why therapeutic interventions could per se not be regarded as cases of intentional bodily harm ${ }^{63}$, i.e. he supported the medical perspective which firmly rejected the notion of surgery as battery ${ }^{64}$. A retired senior official of the Supreme Court, Melchior Stenglein (1825-1903), defended the opposite view that an operation without consent was battery, making also reference to the Hamburg case ${ }^{65}$. As the debate got stuck, two prominent professors of law analysed the whole issue anew: Richard Schmidt (1862-1944) of the University of Freiburg and Ludwig von Bar (1836-1913) at Göttingen.

\section{New attempts to solve the problem, and the consolidation of the battery theory}

Schmidt tried to separate the legal evaluation of medical procedures from the issue of consent. Instead he linked it with what he called "the rules of medical experience". In analogy to the doctors' courts of honour (tribunals for professional conduct), which were being widely established at this time ${ }^{66}$, he suggested to create committees of medical experts. In the name of the court, these committees should scrutinize individual cases to determine whether those rules had been followed. The keeping of the "medical rule" (ärztliche Regel) was for Schmidt the criterion that decided whether a medical intervention was punishable or not ${ }^{67}$. On this basis Schmidt suggested the following legal regulation:

62 Ewald, op. cit. (note 58); Melchior Stenglein, «Operationsrecht des Chirurgen», Deutsche Juristen-Zeitung 4 (1899) 151.

63 C. Stooss, «Die strafrechtliche Natur ärztlicher Handlungen», ibid., 184-186; idem, «Die ärztliche Behandlung im Strafrecht», Schweizerische Zeitschrift für Strafrecht 12 (1899) 24-32; idem, «Die strafrechtliche Natur der ärztlichen Behandlung», Deutsche Medicinische Wochenschrift 25 (1899) 247-248. Further idem, «Aerztliche Behandlung und Körperverletzung», Deutsche Juristen-Zeitung 7 (1902) 566-568, and reprinted in Berliner AerzteCorrespondenz 8 (1903) 6-7.

64 Thiersch, op. cit. (note 2); von Angerer, op. cit. (note 2); Münchener Medicinische Wochenschrift 46 (1899) 203-204, 240, 371-372; Friedrich Scholz, Von Ärzten und Patienten. Lustige und unlustige Plaudereien (Munich ${ }^{4} 1914$ ) 129-133.

65 M. Stenglein, «Die Frage, ob ein Arzt ohne Genehmigung des Patienten [...] eine Operation vornehmen dürfe», Deutsche Juristen-Zeitung 4 (1899) 106-107; idem, «Das Recht des Arztes, zu operieren», Münchener Medicinische Wochenschrift 46 (1899) 525-527.

66 See Andreas-Holger Maehle, "Professional Ethics and Discipline: The Prussian Medical Courts of Honour, 1899-1920”, Medizinhistorisches Journal 34 (1999) 309-338.

67 Richard Schmidt, Die strafrechtliche Verantwortlichkeit des Arztes für verletzende Eingriffe. Ein Beitrag zur Lehre der Straf- und Schuldausschliessungsgründe (Jena 1900) 27-34, 50. 
With reference to "medical custom", as expressed by von Angerer and König, Schmidt wanted to keep patient information and consent, but he made clear that this was "not compulsory, not an object of a formal duty". Only operations against the explicit will of the patient could be punished as cases of coercion or deprivation of personal liberty ${ }^{69}$. Conversely, the doctor should be free of legal responsibility as soon as the patient or his relatives had given consent $^{70}$.

The problematic nature of these proposals, which one-sidedly privileged the interests of the doctor over those of the patient, was highlighted by Ludwig von $\mathrm{Bar}^{71}$. The Göttingen jurist developed instead three preconditions that an operation had to fulfil in order to avoid battery charges against the doctor: 1. the operation had to be performed with the consent of the patient for the purpose of his cure; 2 . it had to be indicated according to the rules of medicine; and 3. it had to be carried out correctly according to the same rules. If one of the last two preconditions were not fulfilled, this constituted battery through negligence, and if consent was lacking, this was intentional bodily harm (vorsätzliche Körperverletzung $)^{72}$.

This synthesis of the views of Oppenheim, von Lilienthal, and also Schmidt, failed, however, in bringing an end to the debate. A new justification for medical interventions without consent was introduced in 1903 by the Strassburg public prosecutor Werner Rosenberg. With reference to $\S \S 677-687$ of the German Civil Code Rosenberg argued that the regulations on management without instruction (Geschäftsfïhrung ohne Auftrag, negotiorum gestio) could be applied to the doctor's treatment of children, the mentally ill, or otherwise severely incapacitated patients, in case of imminent danger (Gefahr im Verzug) ${ }^{73}$. Moreover, he pointed out that certain interventions against the patient's will were permitted, e.g. compulsory vaccination against smallpox on the basis of the German Vaccination Law of

68 Cf. ibid., 37.

69 Ibid., 35-36. On information and consent-seeking as part of medical professional ethics see also Moll, op. cit. (note 50) 243-247; Scholz, op. cit. (note 64) 128, 134.

70 Schmidt, op. cit. (note 67) 36,60.

71 Ludwig von Bar, «Zur Frage der strafrechtlichen Verantwortlichkeit des Arztes», Der Gerichtssaal 60 (1902) 81-112, on 89-91.

72 Ibid., 95-96.

73 Werner Rosenberg, «Strafbare Heilungen», Der Gerichtssaal 62 (1903) 62-83. For legal arguments against this approach see Albert Behr, «Medicin und Strafrecht», ibid., 400-424; Arthur Brückmann, «Neue Versuche zum Problem der strafrechtlichen Verantwortlichkeit für operative Eingriffe. Negatives und Positives», Zeitschrift für die gesamte Strafrechtswissenschaft 24 (1904) 657-714. 
1874 , because they were in the interest of the public ${ }^{74}$. The Bonn professor of law Ernst Zitelmann (1852-1923) took up the suggestion to apply negotiorum gestio, arguing that on this basis an operation on a child to avert imminent danger could be carried out even against the father's will, because his denial of consent was an offence against his duty of maintenance (which included provision of medical care $)^{75}$. Still, also for Zitelmann medical interventions constituted objectively assault and battery, which was not punishable if the patient had consented ${ }^{76}$. Moreover, the Reichsgericht issued decisions on cases in 1907, 1908, and 1911, which emphasized the need for surgeons to obtain the consent of legal representatives in operations on minors, if they wanted to avoid civil law claims for compensation ${ }^{77}$. In 1912 it dealt eventually with the question of how extensive patient information should be, an issue that had been rather neglected so far. In this case an ear operation had gone wrong, resulting in permanent deafness of that ear. The patient's claim for compensation rested, apart from a malpractice charge, on the accusation that the doctor had informed him insufficiently about the risks of the operation $^{78}$. Significantly, the Supreme Court followed here a moderate line, which was comparable to that of von Lilienthal mentioned above and clearly reflected continuing medical paternalism ${ }^{79}$ :

An obligation of the doctor to draw the patient's attention to all disadvantageous consequences that might possibly follow from the recommended operation cannot be recognized. The assumption of such an obligation can neither be derived from the practice of dutiful and careful medical professionals, nor from inner reasons. A comprehensive information of the

74 Rosenberg, op. cit. (note 73) 78-79. For the debate on compulsory vaccination see AndreasHolger Maehle, «Präventivmedizin als wissenschaftliches und gesellschaftliches Problem: Der Streit über das Reichsimpfgesetz von 1874», Medizin, Gesellschaft und Geschichte 9 (1990) 127-148.

75 Ernst Zitelmann, «Die Haftung des Arztes aus ärztlicher Behandlung», Deutsche Medizinische Wochenschrift 33 (1907) 2052-2054, 2098-2101, 2144-2147, on 2101 (with reference to $\$ 679$ BGB). See also Kurt Ehlert, Worin liegt der Grund für die Rechtmässigkeit eines ärztlichen Eingriffes, der ohne Einwilligung des Behandelten oder seines Vertreters vorgenommen wird? (Law thesis University of Heidelberg, Berlin 1909) 51-52.

76 Zitelmann, op. cit. (note 75) 2100.

77 See Spruch-Beilage zur Deutschen Juristen-Zeitung 12 (1907) 1025 and Juristische Wochenschrift 36 (1907) 505-506 (decision of 21 June 1907); Entscheidungen des Reichsgerichts in Zivilsachen. Neue Folge 18 (1908) 431-438 (decision of 27 May 1908); Münchener Medizinische Wochenschrift 58 (1911) 1943 and Juristische Wochenschrift 40 (1911) 748-749 (decision of 30 June 1911). For further relevant decisions see Erwin Deutsch/Monika Hartl/Thomas Carstens (eds), Aufklärung und Einwilligung im Arztrecht. Entscheidungssammlung - Deutsche Urteile seit 1894 (Berlin 1989).

78 Entscheidungen des Reichsgerichts in Zivilsachen, Neue Folge 28 (1912) 432-436 (decision of 1 March 1912).

79 See also Cay-Rüdiger Prüll/Marianne Sinn, "Problems of Consent to Surgical Procedures and Autopsies in 20th Century Germany", in: Andreas-Holger Maehle/Johanna GeyerKordesch (eds), From Paternalism to Autonomy? Historical and Philosophical Perspectives on Biomedical Ethics (Aldershot, forthcoming). 
patient about all possible disadvantageous consequences of the operation would not rarely be actually wrong, whether the patient is deterred by this to undergo the operation, although it is despite its risks necessary or at least advisable, or whether the patient, by imagining the dangers of the operation, is put into a state of fear and agitation and a good course of the operation and cure is thus endangered ${ }^{80}$.

When a revision of the German Criminal Code was debated in the years before the First World War, several medical chambers and lawyers suggested to include regulations that would exempt medically indicated interventions by doctors from prosecution under battery law and introduce a specific clause for punishment of operations that were performed against the explicit will of the patient or his legal representative in the absence of danger ${ }^{81}$. However, there was also opposition against such a step. The Berlin professor of law Wilhelm Kahl (1849-1932) denied, similarly as Stooss had done, that operations could be seen as battery, and brought up again the view of Binding and von Liszt that qualified doctors had a professional right to operate. A new clause in the Criminal Code, he claimed, was thus superfluous ${ }^{82}$. The reform proposals were in fact rejected at an early stage and initially not included in the draft code. Reflecting the views of Kahl, who was a member of the penal reform committee, the motives of the draft denied the need for special regulations of this kind $^{83}$. Yet, the issue was raised again in the Weimar Republic. In 1927 a revised draft was submitted to the Reichstag, suggesting that therapies in line with "conscientious medical practice" should be exempt from battery law and that a regulation on patients' right to refuse treatment should be introduced. However, the draft code was not made law by the Reichstag ${ }^{84}$. This meant in practice that medical interventions continued to be punishable under battery law. It also meant that the consent of the patient, whether explicit or justifiably presumed, kept its central role for their impunity.

80 Entscheidungen (note 78) 433-434.

81 For a compilation and discussion of such proposals see Zitelmann, op. cit. (note 75) 2144. See further Hamm, «Operative Eingriffe der Aerzte», Deutsche Juristen-Zeitung 12 (1907) 447-452.

82 Wilhelm Kahl, «Der Arzt im Strafrecht», Zeitschrift für die gesamte Strafrechtswissenschaft 29 (1909) 351-371.

83 See Joseph Heimberger, «Der Vorentwurf zu einem Deutschen Strafgesetzbuch in seiner Bedeutung für den Arzt», Deutsche Medizinische Wochenschrift 36 (1910) 33-35, 78-81, on 34-35; Ludwig Ebermayer, «Die Stellung des Arztes im Vorentwurf zu einem Deutschen Strafgesetzbuche», ibid. 37 (1911) 1128-1131; idem, «Rechtsfragen aus der ärztlichen Praxis», ibid., 1752-1753; Hans Lieske, «Der ärztliche Eingriff im Spiegel des Rechts», Berliner Klinische Wochenschrift 49 (1912) 1570-1574; Carl Herzberg, Die Grenzen der Straflosigkeit ärztlicher Eingriffe (Law thesis University of Heidelberg, Rietberg 1913) 1.

84 Lutz Sauerteig, «Ethische Richtlinien, Patientenrechte und ärztliches Verhalten bei der Arzneimittelerprobung (1891-1931)», Medizinhistorisches Journal 35 (2000), in press. 


\section{Conclusion}

This article has shown how the legal concept of medical interventions as assault and battery was closely linked with the issue of patients' consent. Advocates of this concept, such as Oppenheim, von Lilienthal and von Bar, gave great importance to consent. The adversaries of that concept, in particular Stooss, Heimberger and Schmidt, thought that obtaining the patient's consent was advisable and in line with medical professional ethics, but wanted to leave that ultimately to the doctor's own judgement in each individual case. German jurisdiction, however, followed the first of these two views, i.e. that of surgery as battery which goes unpunished if the patient or his representative has given consent. The formal requirements for valid consent had initially rather low standards, so that the presumed, tacit consent of the patient was seen as legally sufficient. Likewise, very general information about the risks of surgical procedures was deemed satisfactory from a legal point of view. These standards reflected prevailing medical paternalism and doctors' hostility towards the concept of surgical procedures as physical injury. Still, the battery theory of medical interventions and its legal debate made an important contribution to the development of the modern concept of informed consent in medicine.

\section{Acknowledgements}

I gratefully acknowledge the support of my research by the Wellcome Trust, the British Council, and the University of Durham (Research Committee). Special thanks to colleagues at the Institute for the History of Medicine of the University of Freiburg/Breisgau for their hospitality and friendly support during my research visits. 